\title{
Water Scarcity and Violent Conflict in International Relations: \\ How Process Tracing Contributes to Demystify this Alleged
}

\section{Causal Relationship-The Rio Grande-Colorado Case*}

\author{
Douglas de Castro \\ The São Paulo School of Law-FGV, São Paulo, Brazil
}

\begin{abstract}
In the last few decades, water scarcity and its implications to economic, social and political dimensions has become a hot topic, especially for research agendas that try to establish a causal relationship with violent conflicts. However, these agendas fail to deliver their promises in not providing empirical evidences to confirm theory. In this sense, the present paper provides a fresh look to water scarcity implications, presenting a theoretical framework and new causal mechanism based on complex interdependence theory applied to the physical reality in an international basin. As such, the inferred causal mechanism, its parts and causal direction is investigated applying process-tracing technique to the Rio Grande-Colorado River. The paper finds by tracing the causal mechanism evidences to confirm new theory and enough analytical power to test in other cases to increase confidence in theory to fulfill generalization requirement.
\end{abstract}

Keywords: water scarcity, violent conflict, cooperation, process tracing, international basins

\section{Introduction}

It is a fact that due to the uneven water distribution around the world will cause to be under stress in the near future due to population growth, pressure over the economic output (mostly due to food production) and increasing sources of pollution (WWAP, 2015).

Drawing conclusions over the economic rational (scarce resources increase competition and thus potential for conflicts) it is observed a growing body of research agendas and political rhetoric calling the attention to the potential occurrence of violent conflicts due to water scarcity (Homer-Dixon, 2001).

However, research agendas fail in providing empirical evidences of this causal relationship, as it is observed a different trend in reallity (Gleditsch, 1998). The facts point out to: (1) 263 basins around the world are international; (2) an increasing number of water-related treaties and non-binding agreements; (3) the social, economic and political interaction among countries sharing water resources; and (4) the very low number of violent conflicts triggered by water scarcity itself. ${ }^{1}$

\footnotetext{
* Ackonwledge: Paper submitted to IPSA Rainbow of Methods Conference at the Antwerp University, Belgium. My sincere thanks to CNPQ for funding my research; São Paulo School of Law-FGV for institutional support; my friends Michelle Ratton Sanchez Badin and Rafael Duarte Villa for continuous encouragement; and Derek Beach for introducing process-tracing technique and discussing the work during the conference.

Douglas de Castro, Post-doc researcher, Global Law Center, The São Paulo School of Law-FGV.

1 Retrieved November 23, 2015, from http://www.transboundarywaters.orst.edu/database/
} 
In fact, data provides a different scenario in which States under pressure over shared water tend to engage in cooperative behavior. Therefore, considering the available data on shared water, cooperation and violent conflicts raises the need to investigate the causal relationship between water scarcity and cooperation to respond what the important issues are at stake and in which background conditions it happens.

The main objective of this article is to present a theoretical framework capable of analyzing the conditions in which states are engaging in cooperative behavior instead of violent conflicts under water scarcity scenarios. For that matter, based on the existing literature about trans-boundary water, the framework relies on an inferred causal mechanism, based on the interdependence theory, which is applied traditionally to the economic dimension but in this case to the physical settings in an international river basin.

Applying process-tracing to the case will show that there are strong empirical evidences of the presence of sensitivity and vulnerability effects in the Rio Grande/Colorado river basin that pushes US and Mexico to cooperate considering the "shadow of future", although the study could not exclude the possibility of war or violent conflict. The evidences will be important to generate a more stable theoretical framework to be tested in other cases to increase confidence and, therefore, expanding the debates over social, economic and political implications of water scarcity.

\section{Methodological Approach}

Without making an extensive methodology discussion in this paper, the goal was to make causal process observations thru the application of process tracing technique, which is according to Beach and Pedersen (2013, p.85) "[...] a logical reasoning we formulate a plausible causal mechanism whereby $\mathrm{X}$ produces $\mathrm{Y}$ along with context within which we expect it to operate". It is exactly what Elster (2007) called of "opening the black box of causality".

A causal mechanism as state by Waldner $(2011$, p. 18) is “ ... an agent or entity that has the capacity to alter its environment because it possesses an invariant property that, in specific contexts, transmits either a physical force or information that influences the behavior of other agents or entities", that is to say, is built on parts (agents or entities) and forces that are transmitted to each part of it (such as a transmission belt) forming a causal chain that leads to an outcome. It operates in an analytical level below of a more general theory, increasing credibility and making the new theory more rigorous scientifically (Checkel, 2008; Hedstrom \& Ylikoski, 2010).

The variant of process tracing that is adopted here is the theory-testing one (Beach \& Pedersen, 2013). This variant allows the researcher based on the existing literature and debates to infer the existence of a causal mechanism, and how its parts interact to each other by testing empirically in the selected cases. According to Beach and Pedersen (2013) theorization of the causal mechanism should be made previously to testing based on prior knowledge of the subject and its implications, as we see from the excerpt:

A good starting point for conceptualizing a plausible causal mechanism for a given theorized causal relationship is to start with a thorough reading of the existing theorization on the phenomenon. Review articles are often particularly useful, as are descriptions of the state of the art in peer-reviewed journal articles and books. It is important to note that this reading should be as encompassing as possible. The next step is to game through the different steps of a hypothesized mechanism, filling in the dots between $\mathrm{X}$ and $\mathrm{Y}$ to detail the nuts, bolts, wheels and cogs between them. One way to start this is to draw a mind-map of plausible links between X (or a set of X's) and Y, using boxes to illustrate each part of the mechanism. It is important to remember that each of the parts are insufficient but necessary to produce the outcome in and of themselves. Focus in particular on conceptualizing the entities and their activities. In practice, we cannot always do this, especially as 
regards macro-level mechanisms, where the activities of structural entities are not always self-evident. (pp. 87-88)

The theory used as base to the construction of the causal mechanism is the complex interdependence (Keohane \& Nye, 2012). Usually the theory is applied to the economic domain but given the characteristics of the international basins it is suitable to apply (most the literature uses the term dependency among basin states, but fail to expand the application of such concept if meaning interdependence). According to him, the basic characteristics of the complex interdependence are: (1) multiple channels that connect societies; (2) absence of hierarchy among political issues; and (3) low risk to resource to military capabilities to resolve issues. As the States find themselves in an interdependent relationship, which is the case of states in an international basin, actions promoted in one will provoke negative effects in the other, resulting in the effects of sensitivity and vulnerability (Elhance, 1998; Lowi, 1995).

Therefore, the inferred causal mechanism based on the existing theory is:

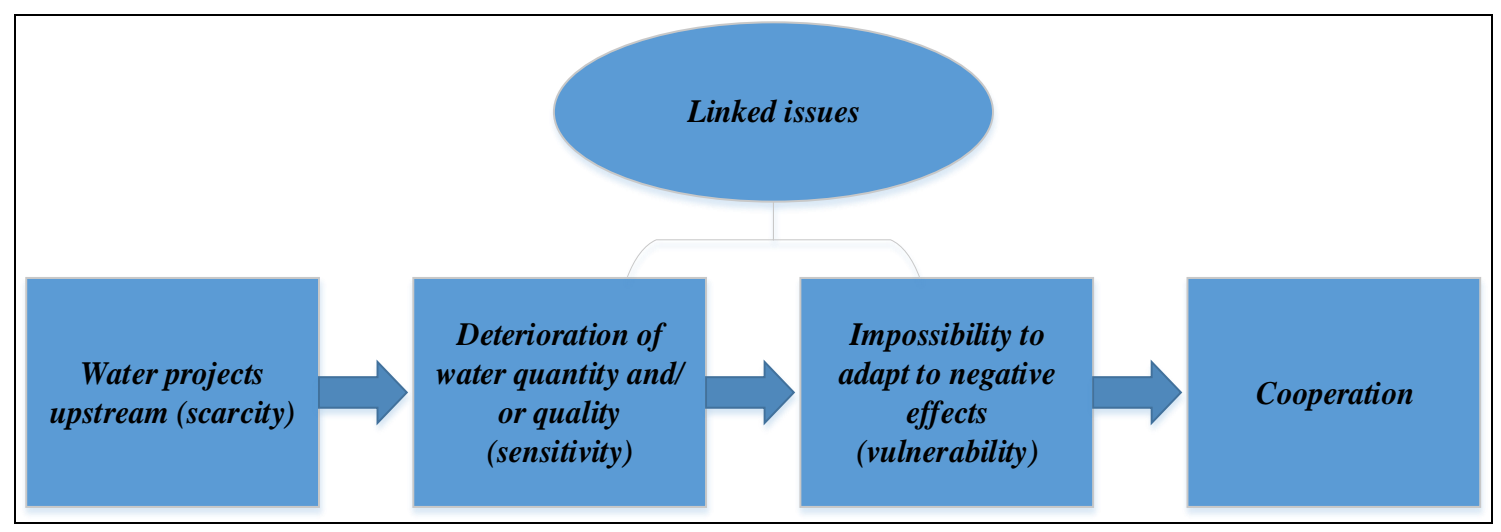

Figure 1. Theoretical framework.

Considering that the purpose is to "to open up the black box" of causality found in the background conditions, the case selection criteria is the typical case one, which the goal is to find representative cases of the theory, meaning cases in which the study variables water scarcity and cooperation are found (Seawright \& Gerring, 2008).

In the next section, the paper shows the empirical testing of the new theory within the limits of the Rio Grande/Colorado case. Water scarcity represented by the salinity crisis and cooperation by the Minute 242 are the conditions in which sensitivity and vulnerability are verified and how linked issues intervenes.

\section{The Rio Grande/Colorado River Case Study: An Empirical Approach}

\section{Introduction}

Waters of the Colorado, Tijuana and Rio Grande rivers run thru a larger extension of the boundary between United States and Mexico. For that matter, it is appropriate the following opening remarks:

In the case of international boundary waters, that is, waters that define at least for part of their course the boundary between two countries, the parties have a more immediate and compelling incentive to come to an understanding because both would likely suffer the consequences of... deterioration of water quality or quantity by the unregulated activities of either or both parties. This self-interest is mutual to the extent that the resource itself is knowingly shared. For river systems, the connection is visible and the mutuality is obvious. (Hall, 2004, p. 873)

In 2012, United States and Mexico signed an agreement under the existing international water regime 
between the countries that makes very clear the urgent need of Mexico's increasing water storage capacity in receiving water from Lake Mead (Nevada and Arizona). On this occasion, the US Interior Secretary Ken Salazar said: "We have chosen collaboration over conflict; we have chosen cooperation and consensus over discord" (Spagat, 2012).

The International Boundary Waters Commission (IBWC or CILA in Spanish) formed in 1944 by both countries intervened directly to facilitate the resolution of issues regarding the borders and the shared waters from Colorado, Rio Grande and Tijuana rivers. The IBWC has been very active since then, promoting several initiatives that account for the success of the cooperation that has kept the region's stability in terms of sharing water (Bernal \& Solis, 2000).

As seen from this introductory note, the comprehensive net of formal agreements are already in place between US and Mexico makes the Rio Grande/Colorado River a typical case for study. As for the temporal dimension, the initial term is the salinity crisis (1961-1973) and the final term signing the Minute 242 (1973). Therefore, present the water scarcity and cooperation conditions the remaining of the paper deals with the empirical evidences that confirms minimally the existence of the inferred causal mechanism.

\section{Background Conditions}

The borders between US and Mexico extends for more than 1954 miles in total length, running thru four states in the US and six states in Mexico, starting in the Pacific Ocean and ending up in the Gulf of Mexico (Witte, Eden, Dos Santos, \& Esqueda, 2012). Although the countries have a points in common, the region is known by its wide range of differences in the resources, regulatory frameworks, development, politics, culture, and language among the large population living in the 36 cities (Weston, 1986) and 80 counties or municipalities (Witte, Eden, Dos Santos, \& Esqueda, 2012).

The border is a very sensitive area in regards to sharing of the waters of the Colorado, Tijuana and Rio Grande rivers due to these differences, which poses a strong pressure over quality and quantity issues connected to usage, environment and development, air and soil pollution, and waste disposal (Weston, 1986).

The settlements in the border region started getting thicker from 1965 with the introduction of the maquiladora program that offered to foreign assembly plants incentives to setup operations in the region. The 1994 North American Free Trade Agreement (NAFTA) introduced the maquiladora feature that increased the industrialization process even more. Thus, the Mexican industrial development concentrated in the border region, adding up to the already large-scale developments existing in the region such as mining and agriculture, all of which needed great amounts of water from the rivers (Shefner, 2007).

As a natural consequence of this process, population of the region increased to 14 million in 2012, being estimated an increment of 9.3 million in the next 20 years or so. This increment will require more infrastructure development (industrial, agriculture and mining), economic growth and job creation, while pollution level will raise bringing serious issues in the public health in both side of the border (Witte, Eden, Dos Santos, \& Esqueda, 2012).

Although both countries have laws to protect the environment against contamination, the soil and water along the borders remain highly polluted. The reason for this is two-fold. First, enforcement of the laws is not as rigorous in the Mexican side of the border as it is in the US (Witte, Eden, Dos Santos \& Esqueda, 2012). Second, there is a large disproportion in the income level of the people living on either side of the border, 
leading to a discrepancy in the amount of available funds (public and private) for pollution containment programs (Frisvold \& Caswell, 2000). Nevertheless, the Mexican government is showing in the recent years a growing interest towards improving environment in the border areas(Witte, Eden, Dos Santos, \& Esqueda, 2012).

\section{Crisis Among Countries}

Water disputes over Rio Grande and Colorado River have social, political and economic implications in both sides of the boarder. Over the years, many disputes have been documented to a point in which US and Mexico established a very sophisticated international legal framework based on the IBWC (IBCW, 2013).

To keep the temporal dimension of our study, the construction of the All-American Canal that brought the salinity crisis is the focal point. The canal construction had the objective to transfer 3.5 million acre feet of water from Colorado to farming lands in the Imperial Valley, California.

Construction and maintenance of the canal led to negative effects in Mexico. The canal runs through arid regions with sandy soil that causes a large amount of water to percolate into the ground, thus decreasing the quantity of water reaching Mexico. In order to alleviate this problem, the United States made plans to line part of the canal. The Mexicans alleged this would not reduce the recharging of the groundwater levels, but also lead to the increase of salinity levels in the aquifer Mesa San Luis, which would cause serious problems to agriculture in the Mexicali valley (Frisvold \& Caswell, 2000).

Widespread protests erupted in the border states of the US because Mexican farmers started to dig ditches in the basin to exploit more water for their agriculture. The Mexican justification was that the water shortage in the region was actually due to the extravagant water usage on the American. This same conflict logic has expanded to the Colorado River, the construction of the Wellton-Mohawk Irrigation e Drainage District of Arizona also caused damages due to salinity (Ingram, 2004).

These protests encouraged the stakeholders in Mexico and the US to urge and advocate an agreement regarding the sharing of the waters of these rivers to prevent similar instances from arising in the future (UMOFF, 2008).

Although the water Treaty signed in 1944 ensured a fair share of the Colorado River water to Mexico (1.5 Million Acre-Feet), the agreement did not provide regulatory instances about water quality reaching Mexico. With the Wellton-Mohawk the water reaching Mexico jumped to 6.000 pmm (parts per million), or in other words, making water unsuitable for agricultural purposes (the salinity level on average was 800 ppm to 1,500 $\mathrm{ppm}$ ). Because of this, the salinity issues added to and even became more controversial than the increasing water scarcity (Kishel, 2000; Johnson, 2000; Mumme, 1993; Frisvold \& Caswell, 2000).

In this sense, the Wellton-Mohawk triggered the salinity crisis among the countries, in which the water project, although complaint with US law and provision regarding water quantity under the 1944 Water Treaty, generated negative effects in Mexico, hitting directly small farms in the Mexicali Valley (Ingram, 2004).

Mexican government complained directly to US about the situation. Although US desired to solve the problem, his positioning... reflected its desire to preserve the existing apportionment formula in the 1944 agreement. Because the quality problem could not be solved, or so it was thought, without affecting the quantity of water delivered to Mexico (Mumme, 1985, p. 628).

Communications to Mexico showed that the US was willing to find a solution to the crisis, however, internally, the government was committed to projects sponsored by local politicians, especially the Wellton-Mohawk, which according to Mumme (1985): 
It was difficult to take any steps to ameliorate the harmful effects of the Wellton-Mohawk drainage. The Bureau of Reclamation was deeply committed to the Wellton-Mohawk Project; Senator Hayden of Arizona, Chairman of the Senate Committee on Appropriations, and Senator Anderson of New Mexico, Chairman of the Senate Committee on Interior and Insular Affairs ( 8 of 17 members of the committee were from the Colorado Basin) were opposed to any ameliorative action that would require additional water for Mexico. (p. 629)

\section{Sensitivity and Vulnerability Perceived in the Basin, Ideology Threat, and Cooperation Outcome}

The importance of the crisis is defined by Senator Mike Mansfield from Montana, majority leader in the House, in these terms:

No other issue in recent times has so troubled our relations [with Mexico]; no other problem has so taxed our determination to seek mutually satisfactory solutions to common problems; no other problem has so tested the sincerity and ingenuity of our diplomats; and no other problem has so challenged the mutual respect and goodwill that our two countries have for each other. ${ }^{2}$

At this point, there is no doubt that water scarcity represented by the salinity levels are present in the relationship between US and Mexico. Furthermore, the negative effects of the Wellton-Mohawk project hit hard Mexico, affecting the necessary uses of water in that region. This provides enough evidence sensitivity's presence and causal force, meaning that the water project in the US produced negative effects in Mexico, triggering actions by government and civil society to contest the project and its results (Neir \& Campana, 2007).

1966 Helsinki Rules, among other international legal instruments, states that countries has the duty to not cause significant harm to other in developing water projects. Note that the principle includes the word "significant", which means that in the relationship between states damages are part of it as long as it is not "significant". However, what constitutes a significant harm? At this point, the vulnerability effect helps to understand this proposition and explain further actions triggered by it (Salman, 2007).

Vulnerability refers to what extent the country that suffers the effects of the interdependence, in this case the high level of salinity provoked by the Wellton-Mohawk project, can absorb the effects or adapt to them.

The high level of salinity in the water reaching Mexico caused serious consequences that prevented using water in agriculture, and for domestic purposes. The estimated impact in costs reached US\$ 53 million in 1973 and if not resolved would reach US\$ 124 million annually in 2010. ${ }^{3}$ As seen, the costs are very high to Mexico, thus, making impossible to adapt considering that the country is under development and highly dependent on water uses for small/family agriculture, which is predominant in the region. In addition, Mexico had no conditions to absorb the negative effects, as the level of salt was so high that it was impossible for historical uses of the water in the region (Mumme, 1993; Witte, Eden, Dos Santos \& Esqueda, 2012; Frisvold \& Caswell, 2000).

The Mexican government in order to alleviate internal pressure started to supply water from different sources to rural workers (campesinos), letting the salty water pass thru Mexicali to Cortés Sea while negotiating a peaceful solution with US (Bernal \& Solís,, 1968).

Therefore, the combination of the US inactivity in not making any progress containing the salty water due to internal political pressures, and the impossibility for Mexico and its farms to internalize the costs or to adapt

\footnotetext{
2120 CONG. REC. S-10371 (daily ed. June 12, 1974).

3 Manhattan Mercury (Kansas), July 24, 1974, p.15.
} 
to the negative effects of the Wellton-Mohawk project, made linked issues in the border an important component to create incentives to US.

The lack of a concrete solution to the salinity problem lead the campesinos to make strong protests in front of the US Consulate in Mexicali that according to Bernal (1968, p. 243) reached around 15,000 campesinos in each protest. The number of protesters was not a problem itself, but the fact is that protests were organized by the Campesina Central Independiente (CCI) and the Movimiento de Liberación Nacional (MLN). To make matters worse, CCI and MLN had a very strong Marxist ideology, exalting during the protests the Mexican Revolution and promoting speeches anti-imperialists directed to US.

Here, linked issues theory plays an important role as an intervening condition (or to use a positivist jargon: intervening variable) that puts more pressure to the existing sensitivity and vulnerability generated by water scarcity. Salinity had already created an important political friction between countries; however, ideology represented by the communist thereat along the border brought additional incentives to speed up a solution. According to Bow (2009):

Linkages, to be clear, are efforts to break an impasse or otherwise improve one's bargaining position on a particular issue by tying it to another, unrelated issue. Linkages can be cooperative or coercive, and they can be prospective (promises, threats) or retrospective (rewards, retaliation). (p. 3)

This was very problematic to the US because it happened at the same time the country was facing the Cuban Missile crises. Therefore, the idea of having another front to battle with communist forces, especially along the land border, was very unpleasant to the US (White, 2007). Government in Washington and society in general felt the threat:

Mexicali-The Colorado — which means reddish — River has brought a flow of left-wing extremists and Communists to Baja California in recent months. The river has brought this flow of Reds because it has supplied two things essential for Marxist propaganda: unrest among the lower working classes and anti-Americanism. (Ruben, 1963)

In a communication loaded with ideology invoking protection of human rights the Comite de la Iniciativa Privada de Mexicalli declared:

Su gobierno inhumana e indebidamente está reteniendo agua utilizable del Río Colorado para consume exclusivo de su país sustituyéndola con aguas de drenaje contaminadas para entrega a México. Consideramos que la actitud de su gobierno constituye acto de privación de derechos y de agresión contra el pueblo de este valle. ${ }^{4}$

In Sonora a protest of 1,200 campesinos become source of attention as it was preparatory to the national rally scheduled to happen in July 12 of that same year according to the Yuma Daily Sun. ${ }^{5}$

The protests got stronger when Alfonso Garzón, the president of the Liga Agraria Estatal, a national rural union became engaged, which led more than 7000 campesinos to protest in front of the American Consulate in Mexico City. Protesters wanted to give back their work visas alleging: "No podemos considerar amigo a un gobierno que arroja los desechos de sus aguas a nuestras tierras, con grave perjuicio a nuestra economía" (Bernal, 2000, p. 287).

The escalation of the protests, Mexico's threat to sue in the UN International Court of Justice, and the ideology permeating the protests called Kennedy's attention. The State Department issued a memorandum

\footnotetext{
${ }^{4}$ In NACP, RG 59, DF, 1960-1963, 611.12322/11-2961, Nov 29, 1961.

5 The Yuma Daily Sun (Arizona), Jun 8, 1964, p. 1.
} 
about the crisis:

Political emotions on this issue are running high in Mexico. The Department [of State] has concluded that our relations with Mexico are so severely strained that immediate action is required to avoid serious damage. There is a possibility that Mexico could successfully carry the issue to International Court ... the political temper in Mexico is such that Mexico will soon be required to take such a step unless constructive action is taken by the United States. ${ }^{6}$

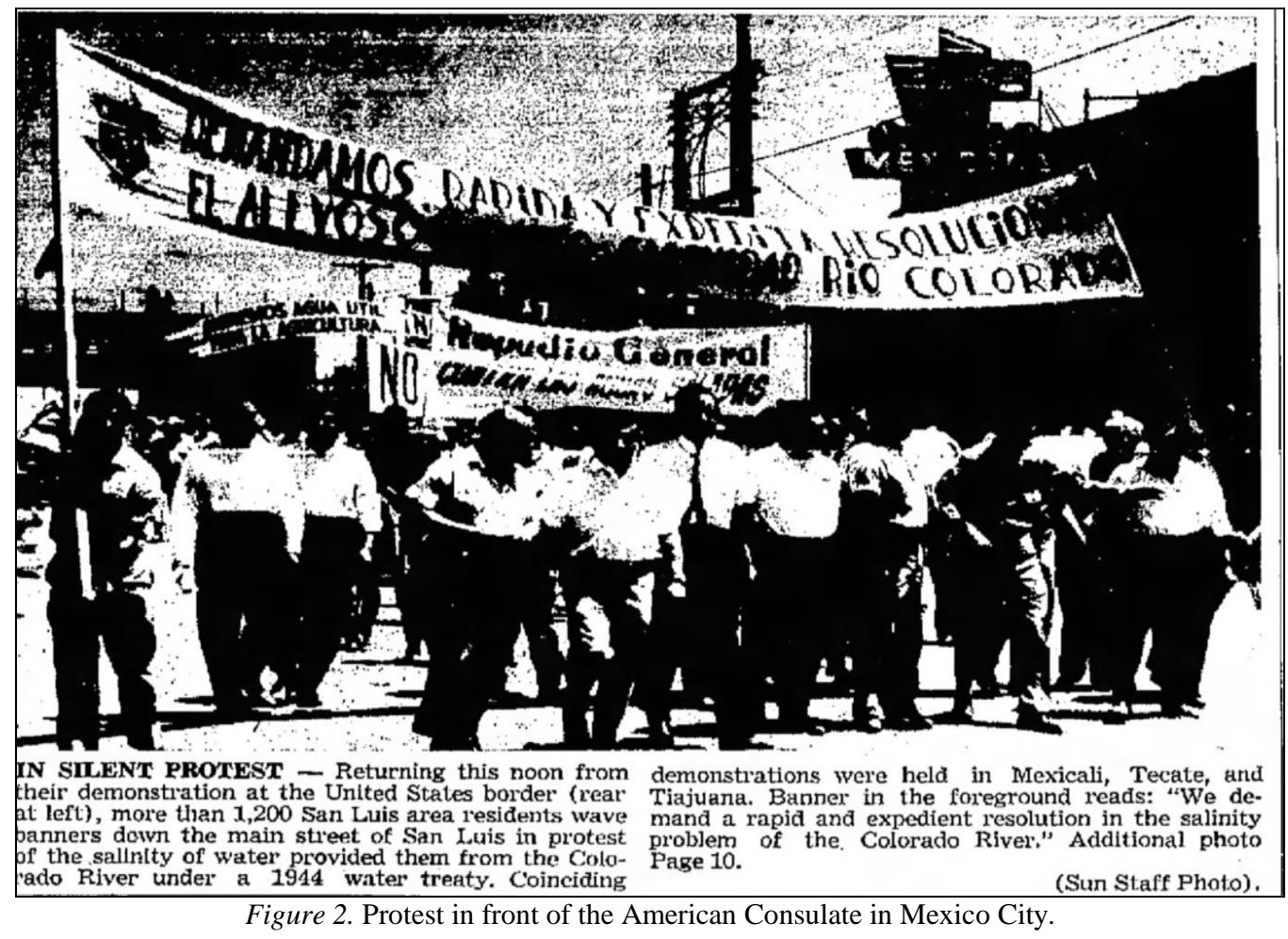

Even the former URSS recognized the seriousness of the issue in a report about Mexican politics and economy:

Besides the differences on economic issues, the Mexican legislators also gave battle about political issues, defending their right to pursue an independent foreign policy with respect to Cuba, foreign trade with China, and the question of [filling] the waters of the Colorado River and other [matters] arose sharply as never before. ${ }^{7}$

Under a legal standpoint, the crisis had its origins in the 1944 Treaty in which negotiations had suggested to include rules about the quality of the water reaching its territory; however, at the end such provision was not included. ${ }^{8}$ However, Mexico contended that US had violated article 3 of the treaty that stated clearly that water flowing to Mexico was for domestic, and agricultural purposes, thus the excessive presence of salt in the water prevented Mexico to use it.

\footnotetext{
${ }^{6}$ In "Memorandum for Mr. McGeorge Bundy, the White House, Subject: Salinity of Colorado River Water", March 14, 1962, NACP, RG 59, DF, 1960-63, 611.12322, 521.1.

7 "Report by the Soviet Academy of Sciences Institute of Latin America, 'Mexico: Politics, Ideology, and the Economy", June 23, 1964, History and Public Policy Program Digital Archive, Archive of the Russian Academy of Sciences, f. 1858, op. 1. d. 109, 1. 1-32. Obtained for CWIHP by VanniPettina and translated by Gary Goldberg. http://digitalarchive.wilsoncenter.org/document/12236

${ }^{8}$ Retrieved November 13, 2015, from http://history.state.gov/historicaldocuments/frus1961-63v10-12mSupp/d204
} 
US response was based on the quantity of water, stating that Mexico was receiving much more water that the minimum stated in the treaty, thus, had no ground to complain as we see from a memorandum issued by Ambassador Mann: “... when Mexico agreed to accept the waters from the Colorado River 'from any and all sources' it agreed to accept underground salt water from Wellton-Mohawk” (p. 6). ${ }^{9}$

Presidents Kennedy and Lopez Mateos commissioned the IBWC to present until October 1963 a solution to the salinity crisis and Kennedy scheduled a visit to Mexico. The direct involvement of Kennedy resulted in internal awareness to the problem, which led US Congress to authorize a budget of US\$ 300.000 to promote scientific studies about the crises. ${ }^{10}$

During Kennedy's visit to Mexico ${ }^{11}$ the issue was discussed in an open meeting between the two presidents, in which Kennedy stated: While there was no provision in the treaty with respect to salt content, the United States should seek in a friendly spirit to help maintain the quality of the water (Memorandum of Conversation, June, 29 1962, p. 1). ${ }^{12}$ In addition, Kennedy stated that he was anxious to solve the problem and would make the necessary efforts in seeking the Congress approval for funds to solve it (p. 2). Kennedy's manifestation was very unusual in diplomatic terms according to Martin (1994):

With the conclusion to the discussion of the two major bilateral issues, on both of which the U.S. admitted to being the guilty party, President Kennedy in a characteristic but unexpected fashion asked me if there were not any issues on which Mexico rather than the US was at fault. (p. 166)

The efforts to solve the problem continued with Johnson ${ }^{13}$, leading to Minute 218 (March 22, 1965) that according to Brownell and Eaton (1975):

The United States engaged in selective pumping of the Wellton-Mohawk drainage wells to alleviate salinity at the times most critical to Mexico and constructed a conveyance channel to facilitate the segregation and bypassing of Wellton-Mohawk drainage to the Gulf of California. The United States invested approximately \$11 million in these and other related works. In addition, under Minute No. 218, the United States released annually approximately 50,000 acre-feet of stored water from above Imperial Dam to meet the Mexican entitlement of 1.5 million acre-feet. (p. 257)

The problem is that Minute 218 did not make the campesinos happy ${ }^{14}$ as although the salinity dropped to $1250 \mathrm{ppm}$, water running to Mexico was still inappropriate to agriculture. Capesinos developed some literature and mailed it to media in Mexico and abroad to explain the situation, which the most representative was the booklet La Sal no debe Separar Dos Pueblos Amigos written by Emilio López Zamora, José Merino Millán and Gustavo Vildosola Almada (Ward, 2003, p. 62).

The booklet described the situation and called the attention to social and economic situation in Mexico that led President Luis Echeverria to threaten to sue the US in the International Court of Justice. US reaction to this immediately when Kissinger, then the President's Assistant of National Security Affairs declared in a memorandum as State Secretary:

\footnotetext{
9 Retrieved November 13, 2015, from http://history.state.gov/historicaldoucuments/frus 1961-63v10-12mSupp/d191

${ }^{10}$ The San Bernardino County Sun, December 14, 1961, pp. 1, 2.

11 Retrieved November 13, 2015, from http://www.jfklibrary.org/Asset-Viewer/Archives/JFKPOF-122-006.aspx

12 Retrieved November 13, 2015, from http://static.history.state.gov/frus/frus1961-63v10-12mSupp/pdf/d194.pdf

13 The Salt Lake Tribune, June 23, 1964, p. 12.

14 Under Minute 218, the United States would build a bypass so that the Mexicans could choose whether to accept this water; the United States, however, would still count the runoff toward its delivery obligations. Retrieved November 13, 2015, from https://muse.jhu.edu/login?auth=0\&type=summary\&url=/journals/technology_and_culture/v046/46.2ellison.pdf
} 
The President has directed that vigorous efforts be made to negotiate as expeditiously as possible a practical settlement of the Colorado River salinity problem with Mexico. The President recognizes there are difficult technical and domestic factors involved, but he wishes the US position to be as forthcoming as possible. Appropriate consultations should be held with congressional representatives and the southwestern states. A report on the status of these negotiations should be submitted to the President by June $30,1971 .^{15}$

With tension once again escalating in the border, Kissinger sent a communication to Nixon on May 6, 1972 that confirms the hypothesis in this paper that complex interdependence and its effects, sensitivity and vulnerability, plays an important role in pushing states to cooperative behavior. Kissinger said:

Frankly, our people recognize that our legal position on salinity is weak. The Mexicans would probably win on their principal point - the demand for better water--under adjudication or arbitration. That, in turn, would mean we would have to make a heavy investment (new wells, channels, etc.) to provide the quality of water Mexico demands (i.e., as good as US farmers get). It would also unquestionably mean submission of a large damage claim by Mexico (for lost or lower quality crops, etc.). The best available estimate is that this would run in the neighborhood of $\$ 85$ million. $^{16}$

Under the threat of litigation in the International Court of Justice, the negative repercussions of the situation internationally, and the recognition by the US of its legal vulnerable position in case of litigation both countries decided to reengage in negotiations, which led to a joint communication:

Regarding the problem of the salinity of the Colorado River, President Echeverria told President Nixon that Mexico reiterates its position as regards receiving its assignment of original waters from the Colorado River, to which the Treaty of February 3, 1944 refers, and therefore, with the same quality as those derived from the Imperial Dam. To this, President Nixon replied that this was a highly complex problem that needed careful examination of all aspects. He was impressed the presentation made by President Echeverria and would study it closely. It was his sincere desire to find a definitive, equitable and just solution to this problem at the earliest possible time because of the importance both nations attach to this matter.

As a demonstration of this intent and of the goodwill of the United States in this connection, he was prepared to: (a) undertake certain actions immediately to improve the quality of water going to Mexico; (b) designate a special representative to begin work immediately to find a permanent, definitive and just solution of this problem; (c) instruct the special representative to submit a report to him by the end of this year; (d) submit this proposal, once it has the approval of this Government to President Echeverria for his consideration and approval. President Echeverria said that he recognized the goodwill of President Nixon and his interest in finding a definitive solution to this problem at the earliest possible time. He added that based on two recent trips to the Mexicali Valley and his talks with farmers there, his Government, while reserving its legal rights, had decided to stop using waters from the Wellton-Mohawk project for irrigation purposes while waiting for receipt of the US proposal for a definitive solution. Both Presidents agreed to instruct their Water and Border Commissioners to prepare and sign a Minute containing the above program and commitments as soon as possible. ${ }^{17}$

The solution came with Minute 242-Permanent and definitive solution to the international problem of the salinity of the Colorado River ${ }^{18}$ —approved by both governments in August 30, 1973, which establishes rights and obligations to the parties, and brings an interpretation that is closer to the spirit of the 1944 treaty with respect to shared water between them. In short the Minute 242 states:

(1) Carrying out necessary works until July 1, 1974 (subject to authorization by the US Congress) to

\footnotetext{
15 Retrieved November 13, 2015, from http://history.state.gov/historicaldocuments/frus 1969-76ve10/d461

${ }_{16}$ Retrieved November 13, 2015, from http://history.state.gov/historicaldocuments/frus 1969-76ve10/d477

1767 DEPT. State Bull. 66 (1972). Retrieved November 13, 2015, from

http://www.ibwc.state.gov/Treaties_Minutes/Minutes.html

18 Retrieved November 13, 2015, from http://www.usbr.gov/lc/region/pao/pdfiles/min242.pdf
} 
contain the salinity of the water supplied to Mexico from the Colorado River, which should not exceed 115ppm, calculated considering the annual average. This eliminates completely any adverse consequence by the Wellton-Mohawk (Resolution 1-A).

(2) Continuous delivery of $172,689,000 \mathrm{~m}^{3}$ of water within the limits of the treaty below Morelos Dam point or at the border that had to keep the salinity limits (resolution $1 \mathrm{~b}$ ).

(3) The expansion of the water diversion drain in Wellton-Mohawk and transportation of the brine to the swamp of Santa Clara in the Gulf of California, which US will pay for (Resolution 4).

(4) US will support Mexican efforts to obtain funding for the improvement and rehabilitation of the Mexicali Valley and will provide on a mutually acceptable basis for negotiation a non-refundable help covering the rehabilitation costs in the valley concerning losses due to salinity (Resolution 7).

(5) The reciprocal limitation on aquifer water pumping to $197,358.000 \mathrm{~m}^{3} /$ year within five-mile area on either side of the international border (Resolution 5).

(6) That the US and Mexico should consult each other before making any new project related to freshwater or aquifers, or make substantial changes to current projects in their own territory and/or border that may adversely affect the other country ( Resolution 6).

(7) That agreement is a permanent and definitive solution to the problem of salinity according to the Presidential Joint Statement of June 1972 (Resolution 8).

As a direct consequence of Minute 242, both countries and IBWC enacted other pieces of legislation addressing water allocation issues between US and Mexico since then, which we will not examine in this paper. Suffice to say that it brought a systemic view in terms of issues related to shared water between them that according to Brownell and Eaton (1975, p. 271) the Minute:

... resolves permanently and definitively an important problem that had plagued their relations for 12 years and also provides for a significant degree of mutual restraint where groundwater pumping by one country affects the other. The two countries have thus, through the agreement, set an example for amicable, practical, and mutually beneficial resolution of problems involving deeply conflicting international and domestic interests between nations in the Americas.

\section{Conclusion}

The salinity crisis offers a very clear view of how political issues (national and international), scientific, economic, social and environmental are interconnected in such a way that the adoption of a holistic approach becomes increasingly necessary. It highlighted the trend that, at a certain point of the conflict installed between riparian countries, whether violent or not, recognition of the physical interdependence an important condition leading countries to cooperation processes.

The analysis of the Rio Grande/Colorado case shows enough evidences that phisical interdependence generated sensitivity and vulnerability effects that moved US and Mexico to a complex negotiation process, which was magnified by the ideological dimension of their relationship raised during the salinity crisis.

Therefore, empirical evidences found in the exam of the case confirm the internal validity of the theoretical model as inferred on page three of this work. The application of the theoretical model to the empirical dimension assumes the conclusion as expressed below in the graphic.

The construction of the Welton-Mohawk project has provoked a substantial change in the quality of the water reaching Mexico. Water was diverted from Colorado River to be used in irrigation projects, returning to river stream in quantity enough to the US to meet the obligations assumed in the Water Treaty; however, with 
such a high level of salt that made historical and necessary uses by Mexico impossible. This meets with the water scarcity conceptualization in this work.

The effect of sensitivity is found in the case as a direct result of the Welton-Mohawk project in which domestic and agricultural uses were prevented in Mexico by local community that depended on directly on water quality.

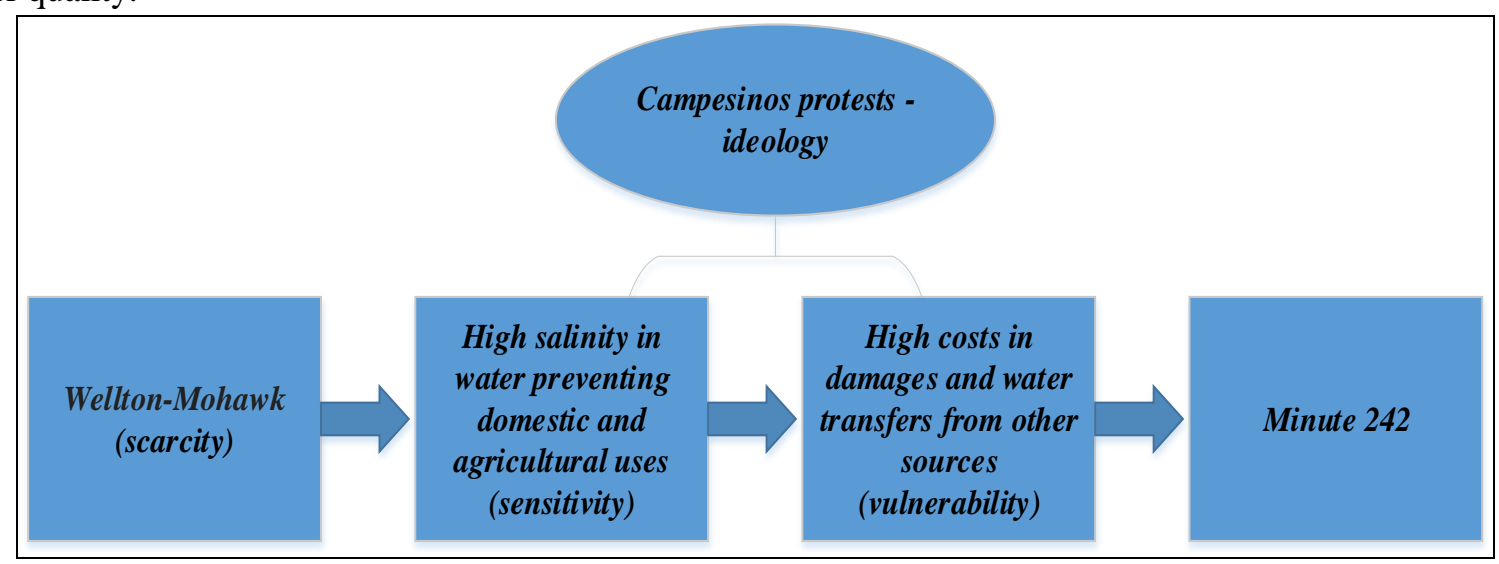

Figure 3. Empirical manifestation of the theory.

In order to get around of the negative effects Mexico considered adopting other measures to mitigate them, which among them was diverting water from Rio Grande proved to be costly and would harm farmers in the US. In addition, environment was already suffering with high level of salt, becoming an important issue between the countries. This makes the vulnerability effect present in the case as theorized.

Sensitivity and vulnerability had already casual forces to move actors to find a peaceful solution to the conflict. However, the causal force of these two effects were magnified by the communist ideology present on Campesinos protests in the border, thus, accelerating the negotiation timeline between Mexico and US, being this one already under pressure due to former URSS influence expansion, especially considering the Cuban issue.

The materialization of the cooperation between Mexico and US to resolve the salinity crisis was reached by the adoption of the Minute 242 and the creation of the IBWC. Mexico and US had already in place the Water Treaty to prevent conflicts over water allocation, which did not prevent them to find themselves in a position that cooperation more than an end in itself is a process depending on dynamics of social and natural forces. Although the present study does not exclude the possibility of violent conflicts over scarce water resources and recognizes that other causal forces might intervene in the model, the causal direction and parts of the inferred causal mechanism as presented are plausible and consistent with data and literature.

\section{References}

Beach, D., \& Pedersen, R. B. (2013). Process-tracing methods: Foundations and guidelines. The University of Michigan Press. Bernal, C. A. (1968). COMPENDIO HISTORICO-BIOGRAFICO DE MEXICALI 1539-1966. Celso Aguirre Bernal.

Bernal, J. M., \& Solís, A. H. (2000). Conflict and cooperation on international rivers: The case of the Colorado River on the US-Mexico border. International Journal of Water Resources Development, 16(4), 651-660. doi:10.1080/07900620020003155

Bow, B. (2009). The politics of linkage. UBC Press.

Brownell, H., \& Eaton, S. D. (April 1975). The Colorado River salinity problem with Mexico. The American Journal of International Law, 69(2), 255-271. doi:10.2307/2200267 
Checkel, J. T. (2006). Tracing causal mechanisms. International Studies Review, 8(2), $362-370$. doi:10.1111/j.1468-2486.2006.00598_2.x

Elhance, A. (1999). Hydropolitics in the third world: Conflict and cooperation in international river basins. United States Institute of Peace.

ELSTER, J. (2007). Explaining social behavior: More nuts and bolts for the social sciences. Cambridge; New York: Cambridge University Press.

Frisvold, G. B., \& Caswell, M. F. (2000, December). Transboundary water management: Game-theoretic lessons for projects on the US-Mexico Border. Agricultural Economics, 24(1), 101-111. doi:10.1016/S0169-5150(00)00118-3

Gleditsch, N. P. (1998, May 1). Armed conflict and the environment: A critique of the literature. Journal of Peace Research, 35(3), 381-400. doi:10.1177/0022343398035003007

Hall, R. E. (2004). Transboundary groundwater management: Opportunities under international law for groundwater management in the United States-Mexico border region. Arizona Journal of International \& Comp. L, 21, 873-874.

Hedström, P., \& Ylikoski, P. (2010). Causal mechanisms in the social sciences. Annual Review of Sociology, 36(1), 49-67. doi:10.1146/annurev.soc.012809.102632

Homer-Dixon, T. F. (2002). The ingenuity gap: Facing the economic, environmental, and other challenges of an increasingly complex and unpredictable world. New York: Vintage Books.

Homer-Dixon, T. F. (2001). Environment, scarcity, and violence. Princeton University Press (2001) Paperback. Princeton University Press.

IBWC. (2013). History of the US Section. International Boundary \& Water Commission: United States and Mexico. Retrieved January 23, 2013, from http://www.ibwc.state.gov/About-Us/history.html.

Ingram, H., \& White, D. R. (2008). International boundary and water commission: An institutional mismatch for resolving transboundary water problems. Natural Resources Journal (NATUR RESOUR J), 33(1), 154-175.

Ingram, S. G. (2004). In a Twenty-First Century “Minute”. Natural Resources Journal, 44(1), 163-211.

Johnson, R. W. (2000). The Colorado River: History and contemporary issues of a complex system. In E. Mostert (Ed.), River basin management: Proceedings of the International Workshop (The Hague, October 27-29 1999) (pp. 114-125). Paris: UNESCO.

Keohane, R. O., \& Nye, J. S. (2012). Power and interdependence. Boston: Longman.

Kishel, J. (2000). Lining the all-American canal: Legal problems and physical solutions. Natural Resources, 33, 697-726.

Littlefield, D. R. (2008). Conflict on the Rio Grande: Water and the law, 1879-1939. Norman: University of Oklahoma Press.

Lowi, M. R. (1995). Water and power: The politics of a scarce resource in the Jordan River Basin. Cambridge [England]; New York, NY, USA: Cambridge University Press.

Martin, E. M. (1994). Kennedy and Latin America. Lanham University Press of America.

Memorandum of Conversation. (1969). US State Department. http://static.history.state.gov/frus/frus1961-63v10-12mSupp/pdf/d194.pdf

Mumme, S. P. (1985, December). State influence in foreign policymaking: Water related environmental disputes along the United States-Mexico border. The Western Political Quarterly, 38(4), 620-640.

Mumme, S. (1993). Innovation and reform in transboundary resource management: A critical look at the international boundary and water commission, United States and Mexico. Natural Resources, 93-120.

Neir, A. M., \& Campana, M. E. (2007). The peaceful resolution of US-Mexican transboundary water disputes. The Economics of Peace and Security Journal, 2(2), 42-48.

Ruben, S. (1963). River Row Makes Reds Flood Baja California. Los Angeles Times, p.10.

Salman, M. A. S. (2007, December). The Helsinki rules, the UN watercourses convention and the Berlin rules: Perspectives on international water law. Water Resources Development, 23(4), 625-640.

Seawright, J., \& Gerring, J. (2008, June 1). Case selection techniques in case study research a menu of qualitative and quantitative options. Political Research Quarterly, 61(2), 294-308. doi:10.1177/1065912907313077

Shefner, J. (2007, March 1). Rethinking civil society in the age of NAFTA: The case of Mexico. Annals of the American Academy of Political and Social Science, 610, 182-200.

Spagat, E. (2012, November 20). US, Mexico rewrite rules on sharing Colorado river. CBS Denver. Retrieved January 15, 2013, from http://denver.cbslocal.com/2012/11/20/us-mexico-rewrite-rules-on-sharing-colorado-river/

Umoff, A. A. (2008). An analysis of the 1944 US-Mexico water treaty: Its past, present, and future. Environs: Environmental Law and Policy Journal, 32(1), 69-98. 
Waldner, D. (2012). Process Tracing and causal mechanisms. In The Oxford Handbook of Philosophy of Social Science. Oxford University Press.

Ward, E. R. (2003). Border oasis-water and the political ecology of the Colorado River delta. University of Arizona Press.

Weston, S. N. (1986). United States-Mexico: Coping with environmental problems at the border. Loyola of Los Angeles International and Comparative Law Review, 117-136.

White, C. M. (2007). Creating a third world: Mexico, Cuba, and the United States during the Castro Era. Albuquerque: University of New Mexico Press.

Witte, B., Eden, S., Dos Santos, P., \& Esqueda, J. S. (2012). WRRC, Arroyo, p. 12, Water Resources Research Center, Tucson, $A Z$.

Wolf, A. T. (1998). Conflict and cooperation along international waterways. Water Policy, 1(2), $251-265$. doi:10.1016/S1366-7017(98)00019-1

United Nations World Water Assessment Programme (WWAP). (2015). The United Nations World Water Development Report 2015: Water for a Sustainable World. Paris, UNESCO. 